\title{
Analysis and findings from the Zimbabwe supply chain human resource assessment
}

\author{
Brian Serumaga ${ }^{1 *}$, Rachel Kearl ${ }^{1}$, Misheck Ndlovu ${ }^{2}$, Tinei Chisike ${ }^{3}$ \\ From The 2nd People that Deliver (2nd PtD) Global Conference on Human Resources in Supply Chain \\ Management \\ Copenhagen, Denmark. 29-30 October 2014
}

\begin{abstract}
Background
Although progress has been made in growing Zimbabwe's public sector health commodity supply chain, human resource challenges remain. To understand and address these challenges, the Ministry of Health and Child Welfare (MOHCW) Directorate of Pharmacy Services (DPS), with support from the USAID|DELIVER Project, conducted a human resources (HR) capacity assessment in March 2012 that: documented the state of supply chain HR capacity, identified opportunities to build HR capacity, documented professionalization efforts of supply chain personnel.
\end{abstract}

\section{Method}

We used the USAID|DELIVER Project Human Resource Capacity Development Assessment Guide and Tool to evaluate Zimbabwe's public health supply chain HR based on five components: powerful constituencies, policies and plans, workforce development, workforce performance management, and professionalization.

Investigators: gathered data using focus groups at central, provincial, district, and health facility levels, surveyed two urban (Harare, Bulawayo) and two rural (Matebeleland South, Mashonaland East) provinces, and surveyed $\mathrm{MOHCW}$, city, and mission-managed facilities.

\section{Results}

The assessment team carried out a detailed analysis of each component based on collected data. They examined internal strengths and weaknesses of the system and external opportunities and threats. Broad findings included: limited funding for positions with supply chain responsibilities and significant reliance on donors for the staffing of key positions, inadequate coordination and

\footnotetext{
* Correspondence: bserumaga@jsi.com

'USAID | DELIVER PROJECT, John Snow, Inc. Washington DC, USA

Full list of author information is available at the end of the article
}

communication of workforce resources and expectations among MOHCW's departments (pharmacy services, nursing services, and human resources), and low staff retention due mainly to lower compensation rates for staff in public health facilities compared to colleagues in the private sector.

\section{Discussion}

The following support would strengthen HR management for the health supply chain in Zimbabwe: create an HR coordination group that includes senior management from different health departments in the MOHCW, incorporate supply chain cadres into the existing HR retention scheme supported by The Global Fund To Fight AIDS, Tuberculosis and Malaria (GFATM), utilize district medical officers to improve HR information dissemination for supply chain cadres across all levels, update the staffing structure and clarify roles and expectations to reflect current supply chain requirements, implement an enhanced mentoring program to accelerate development and retention of supply chain cadres, and develop and implement supply chain pre-service training for allied health cadres.

\section{Lessons learned}

This assessment found challenges for health workers with supply chain responsibilities in Zimbabwe. Nevertheless, the assessment also revealed that practical and less costly interventions could yield substantial improvements in the short and long terms. These interventions include better coordination, improved commissioning of existing resources, and long-term investments in training.

\footnotetext{
Authors' details

'USAID | DELIVER PROJECT, John Snow, Inc. Washington DC, USA. ${ }^{2}$ Ministry of Health and Child Welfare, Harare, Zimbabwe. ${ }^{3}$ USAID | DELIVER PROJECT Zimbabwe, John Snow Inc., Harare, Zimbabwe.
}

C Biomed Central

(c) 2014 Serumaga et al; licensee BioMed Central Ltd. This is an Open Access article distributed under the terms of the Creative Commons Attribution License (http://creativecommons.org/licenses/by/4.0), which permits unrestricted use, distribution, and reproduction in any medium, provided the original work is properly cited. The Creative Commons Public Domain Dedication waiver (http://creativecommons.org/publicdomain/zero/1.0/) applies to the data made available in this article, unless otherwise stated. 
Cite this article as: Serumaga et al:: Analysis and findings from the

Zimbabwe supply chain human resource assessment. Journal of

Pharmaceutical Policy and Practice 2014 7(Suppl 1):P1.

Submit your next manuscript to BioMed Central and take full advantage of:

- Convenient online submission

- Thorough peer review

- No space constraints or color figure charges

- Immediate publication on acceptance

- Inclusion in PubMed, CAS, Scopus and Google Scholar

- Research which is freely available for redistribution 